\title{
1 An Immunobridging study to evaluate the neutralizing antibody titer in adults \\ 2 immunized with two doses of either ChAdOx1-nCov-19 (AstraZeneca) or \\ 3 MVC-COV1901.
}

4

5 Josue Antonio Estrada ${ }^{1}$,Chien-Yu Cheng ${ }^{2,3,}{ }^{*}$, Shin-Yen $\mathrm{Ku}^{4}$, Hui-Chun $\mathrm{Hu}^{4}$, Hsiu-Wen $\mathrm{Yeh}^{4}$,

6 Yi-Chun Lin ${ }^{2}$, Cheng-Pin Chen ${ }^{2,5}$, Shu-Hsing Cheng ${ }^{2,6}$, I-Feng Lin ${ }^{3 * *}$

$8 \quad{ }^{1}$ Medigen Vaccine Biologics, Taipei, Taiwan

$9{ }^{2}$ Department of Infectious Diseases, Taoyuan General Hospital, Ministry of Health and Welfare,

10 Taoyuan, Taiwan

$11{ }^{3}$ Institute of Public Health, School of Medicine National Yang-Ming Chiao Tung University

$12{ }^{4}$ Department of Nursing, Taoyuan General Hospital, Ministry of Health and Welfare, Taoyuan,

13 Taiwan

$14{ }^{5}$ School of Clinical Medicine, National Yang-Ming Chiao Tung University, Taipei, Taiwan

$15{ }^{6}$ School of Public Health, Taipei Medical University, Taipei, Taiwan

16

17 *Corresponding author: Chien-Yu Cheng, Division of Infectious Diseases, Department of Internal

18 Medicine, Taoyuan General Hospital, Ministry of Health and Welfare, No. 1492, Zhongshan Rd.,

19 Taoyuan Dist., Taoyuan City 330, Taiwan (R.O.C.), Tel: +886-3-3699721, E-mail: 
medRxiv preprint doi: https://doi.org/10.1101/2022.02.26.22271364; this version posted March 1, 2022. The copyright holder for this preprint (which was not certified by peer review) is the author/funder, who has granted medRxiv a license to display the preprint in perpetuity.

It is made available under a CC-BY 4.0 International license .

21 **Alternative corresponding author: I-Feng Lin Prof. Institute of Public Health, School of

22 Medicine National Yang-Ming Chiao Tung University, 155 Li-Nong Street, Pei-Tou, Taipei, Taiwan

23 R.O.C Tel: +886-2-28267311, E-mail: iflin@ nycu.edu.tw 
medRxiv preprint doi: https://doi.org/10.1101/2022.02.26.22271364; this version posted March 1, 2022. The copyright holder for this preprint (which was not certified by peer review) is the author/funder, who has granted medRxiv a license to display the preprint in perpetuity.

It is made available under a CC-BY 4.0 International license .

\section{Abstract}

\section{Background}

26 Rapid development and deployment of vaccine is crucial to control the continuously evolving

27 COVID-19 pandemic. Placebo-controlled phase 3 efficacy trial is still standard for authorizing

28 vaccines in majority of the world. However, due to lack of cases or participants in parts of the world,

29 this has not always been feasible. An alternative to efficacy trial is immunobridging, in which the

30 immune response or correlates of protection of a vaccine candidate is compared against an approved

31 vaccine. Here we describe a case study where our candidate vaccine, MVC-COV1901, has been

32 granted for emergency use authorization (EUA) locally based on the non-inferiority immunobridging

33 process.

$34 \quad$ Methods

35 The per protocol immunogenicity (PPI) subset from the MVC-COV1901 phase 2 trial was used for 36 this study and consisted of 903 subjects who have received two doses of MVC-COV1901 as scheduled

37 in the clinical trial. The comparator set of population consisted of 200 subjects of $\geq 20$ years of age

38 who were generally healthy and have received two doses of AstraZeneca ChAdOx nCOV-19

39 (AZD1222) recruited from Taoyuan General Hospital, Ministry of Health and Welfare.

\section{Results}

MVC-COV1901 was shown to have a geometric mean titer (GMT) ratio lower bound 95\% confidence interval (CI) of 3.4 against the comparator vaccine and a seroconversion rate of $95.5 \%$ at

43 the $95 \%$ CI lower bound, which both exceeded the criteria set by the Taiwan regulatory authority for

44 EUA approval. These results supported the EUA approval of MVC-COV1901 by the Taiwanese 45 regulatory authority in July 2021. Following the consensus of the International Coalition of Medicines 46 Regulatory Authorities (ICMRA), countries from the Access Consortium has recently adopted the use 47 of immunobridging studies as acceptable for authorizing COVID-19 vaccines in lieu of efficacy data. 
medRxiv preprint doi: https://doi.org/10.1101/2022.02.26.22271364; this version posted March 1, 2022. The copyright holder for this preprint (which was not certified by peer review) is the author/funder, who has granted medRxiv a license to display the preprint in perpetuity.

It is made available under a CC-BY 4.0 International license .

\section{$50 \quad$ Conclusion}

51 The data presented in the study showed that it is reasonably likely that the vaccine efficacy of

52 MVC-COV1901 is similar or superior to that of AZ. Data could be used in support of further vaccine

53 development and regulatory approval. 
medRxiv preprint doi: https://doi.org/10.1101/2022.02.26.22271364; this version posted March 1, 2022. The copyright holder for this preprint (which was not certified by peer review) is the author/funder, who has granted medRxiv a license to display the preprint in perpetuity.

It is made available under a CC-BY 4.0 International license .

\section{Introduction}

$55 \quad$ MVC-COV1901 is a protein subunit SARS-CoV-2 vaccine based on the stabilized prefusion spike 56 protein S-2P adjuvanted with CpG 1080 [1]. From 2020 to early 2021, Taiwan has been spared from

57 the worst of the pandemic, which recorded only a total of local and imported of 525 cases in 2020 and

58339 cases in 2021 prior to the local outbreak in May 2021 [2]. As a result, it was not feasible to conduct

59 placebo-controlled efficacy trial locally in Taiwan at the time. In response, Taiwan health authorities

60 designed a pathway to EUA for all local vaccine candidates based on immunobridging, which

61 compares the immune response of a vaccine candidate with an approved vaccine for comparison [3].

62 Over 3,800 participants were enrolled in a phase 2 clinical trial for MVC-COV1901 and the results of

63 this large-scale phase 2 trial allowed the Taiwan regulatory authorities to examine the safety and

64 immunogenicity to the comparator vaccine which has already been approved in Taiwan for

65 non-inferiority [3, 4]. MVC-COV1901 was approved by the Taiwan Food and Drug Administration

66 (TFDA) in July 2021, making it among the first COVID-19 vaccine approved using immunobridging

67 study prior to the availability of efficacy data [5]. In June 2021, experts from regulatory authorities

68 around the world convened at a workshop for the future of COVID-19 vaccine development, and

69 consensus was reached for the use of well-justified and appropriately designed immunobridging

70 studies in place of clinical endpoint efficacy studies when they are not feasible [6]. In September 2021,

71 the consensus position has since been taken up by the Access Consortium, which consisted of

72 regulatory authorities from the UK, Australia, Canada, Singapore and Switzerland, to accept

73 immunobridging studies as sufficient for authorizing COVID-19 vaccines in these countries [7, 8].

74 This manuscript thus illustrates an example of a COVID-19 vaccine approved with immunobridging

75 study, which has gradually become recognized by health regulatory authorities worldwide. 
medRxiv preprint doi: https://doi.org/10.1101/2022.02.26.22271364; this version posted March 1, 2022. The copyright holder for this preprint (which was not certified by peer review) is the author/funder, who has granted medRxiv a license to display the preprint in perpetuity.

It is made available under a CC-BY 4.0 International license .

\section{Methods}

\section{Clinical trial and sample population}

The MVC-COV1901 phase 2 trial was a prospective, randomized, double-blind, placebo-controlled, and multicenter study to evaluate the safety, tolerability, and immunogenicity of the SARS-CoV-2 vaccine candidate MVC-COV1901 (NCT04695652) [4]. The main study of the trial consisted of 3,844 subjects of $\geq 20$ years of age who were generally healthy or with stable pre-existing medical conditions recruited from eleven sites in Taiwan, and this population was used for safety analysis [4]. The per protocol immunogenicity (PPI) subset from the MVC-COV1901 phase 2 trial was used for this study and consisted of 903 subjects who have received two doses of MVC-COV1901 as scheduled in the clinical trial. The comparator set of population consisted of 200 subjects of $\geq 20$ years of age who were generally healthy and have received two doses of AstraZeneca ChAdOx nCOV-19 (AZD1222) recruited from Taoyuan General Hospital, Ministry of Health and Welfare.

$$
\text { The trial protocol and informed consent form were approved by the Taiwan Food and Drug }
$$
Administration (FDA) and the ethics committees at the participating sites. The institutional review boards included the Chang Gung Medical Foundation, National Taiwan University Hospital, Taipei Veterans General Hospital, Tri-Service General Hospital, Taipei Medical University Hospital, Taipei Municipal Wanfang Hospital, Taoyuan General Hospital Ministry of Health and Welfare, China Medical University Hospital, Changhua Christian Hospital, National Cheng Kung University Hospital, and Kaoshiung Medical University Hospital. The trial was done in accordance with the principles of the Declaration of Helsinki and good clinical practice guidelines.

\section{Vaccines}

Medigen COVID-19 vaccine or MVC-COV1901, a subunit vaccine consisting of the prefusion spike protein (S-2P) adjuvanted with $750 \mu \mathrm{g}$ CpG 1018 and $375 \mu \mathrm{g}$ aluminum hydroxide. A standard $0.5 \mathrm{~mL}$ dose contains $15 \mu \mathrm{g}$ of the Spike-2P. Both are delivered instramuscularly at the deltoid region. The comparator vaccine is ChAdOxAZD1222, an adenoviral vector vaccine developed by Oxford 
medRxiv preprint doi: https://doi.org/10.1101/2022.02.26.22271364; this version posted March 1, 2022. The copyright holder for this preprint (which was not certified by peer review) is the author/funder, who has granted medRxiv a license to display the preprint in perpetuity.

It is made available under a CC-BY 4.0 International license.

106 University and AstraZeneca served at multi-dose vials. Each dose of vaccine is $0.5 \mathrm{~mL}$ and contains

$1075 \times 10^{10}$ viral particles.

108

109 Immunobridging study

110 According to the TFDA document, the follow criteria were set for a candidate vaccine to be 111 granted EUA in Taiwan [3]:

112 - Clinical data: Immunobridging study to evaluate the immunogenicity of locally developed

113 vaccine against a comparator vaccine which has already been approved in Taiwan.

114 - Safety data: At least 3,000 subjects were required to be tracked for at least one month for 115 safety data after the last dose and all subjects to be followed for a median of two months 116 after the last dose.

117 As the AstraZeneca ChAdOx1 nCoV-19 (AZD1222) vaccine was the first COVID-19 vaccine to be 118 approved in Taiwan, it was chosen as the comparator vaccine for which the locally developed vaccines 119 are to be benchmarked with [3]. The immunobridging criteria were to fulfill the following endpoints 120 for serum samples 28 days after the second dose (Day 57) in population under the age of 65 [3, 9]:

121 1. The lower limit of the $95 \%$ confidence interval of the geometric mean titer ratio (GMTR) of the prototype strain live virus neutralizing antibodies for the MVC-COVID19 vaccine group to the external control group must be greater than 0.67 , as shown in a blood test 28 days after the second dose;

2. The sero-response level was defined as the neutralizing antibody titers against the prototype strain live virus at 28 days after receiving the second dose of the vaccine, at the referred point of $60 \%$ reverse accumulative distribution curve for external control group The lower limit of the $95 \%$ confidence interval for the sero-response rate (the proportion of subjects whose neutralizing antibody titers against the prototype strain live virus, at 28 days after receiving the second dose of the MVC-COVID19 vaccine are above the sero-response level) must be greater than $50 \%$ 
medRxiv preprint doi: https://doi.org/10.1101/2022.02.26.22271364; this version posted March 1, 2022. The copyright holder for this preprint (which was not certified by peer review) is the author/funder, who has granted medRxiv a license to display the preprint in perpetuity.

It is made available under a CC-BY 4.0 International license.

\section{Live SARS $\square \operatorname{CoV} \square 2$ neutralization assay}

133 Neutralizing antibody titers against the Wuhan prototype SAR-CoV-2 were determined by

134 SARS-CoV-2 live virus neutralization assay as described previously [4].

\section{Statistical analysis}

137 Descriptive statistics were obtained and presented for the population's characteristics. GMTs

138 were estimated from neutralizing antibody titers measured at 28 days after the second dose of the study

139 intervention. Geometric mean titer ratio (GMTR) is calculated as the GMT of MVC group over the

140 GMT of AZ group.

141 The GMTs are presented with their two-sided 95\% CI. To assess the magnitudes of differences in 142 immune response between the two vaccines, an analysis of covariance (ANCOVA) model was used.

143 The model included the log-transformed antibody titers at Day 57 as the dependent variable, vaccine 144 group (AZD1222 and MVC-COV1901) as an explanatory variable and adjusted for age, BMI, gender 145 and comorbidity profile. The 95\% CI for the adjusted neutralizing antibody titers of each vaccine 146 group were obtained. Then adjusted GMT and corresponding 95\% CI were back-transformed to the 147 original scale. A worst modified subset of the sample was created which included only GMT values $\leq$ 148 67th percentile at Day 57. Reverse cumulative distribution (RCD) curves were constructed for data 28 149 days after the $2^{\text {nd }}$ dose for the AZD1222 and MVC-COV1901 groups.

\section{$151 \quad$ Results}

\section{Demographics}

The mean age of AZD1222 (AZ) and MVC-COV1901 (MVC) groups were similar at 42.9 and

15445.7 years, respectively (Table 1). However, only six (3\%) subjects were over age of 65 in the AZ 155 group compared to 221 (24.4\%) in MVC-COV1901, though this is due to the study design of the 156 MVC-COV1901 trial to enroll at least 20\% of participants to be over age of 65 [4]. In terms of gender, 157 the AZ group had higher percentage of females (59.8\%) than that of MVC group (42.3\%). Other 
medRxiv preprint doi: https://doi.org/10.1101/2022.02.26.22271364; this version posted March 1, 2022. The copyright holder for this preprint (which was not certified by peer review) is the author/funder, who has granted medRxiv a license to display the preprint in perpetuity.

It is made available under a CC-BY 4.0 International license .

158 discrepancies between the two groups include the higher proportion of comorbidity in the AZ group

159 (38.1\%) compared to the MVC group (19.3\%). In order to investigate the effects of these factors for

160 the immunobridging process, we performed sensitivity analyses based on age group, gender, and

161 comorbidity.

162

\section{Immunogenicity}

In subjects of under age of 64 , at 28 days after the second dose, the AZ and MVC groups had

GMTs of 186 and 733, respectively (Figure 1). When including the above 65 years of age into the

GMT calculation, the GMTs decreased to 184 and 662 for the AZ and MVC groups, respectively, due

to the inclusion of lower neutralizing antibody titer levels in the older age group (Figure 1). According

to the analysis for immunobridging study, the results showed that the lower limit of the $95 \% \mathrm{CI}$ for the

169 GMTR of the prototype strain live virus neutralizing antibodies between MVC and AZ groups was 3.4

170 times, which was greater than the requirement of 0.67 times. The lower limit of the $95 \%$ confidence

171 interval for the sero-response rate of the MVC group was 95.5\%, which was greater than the 172 requirement of $50 \%$.

173 Illustrated in Figure 2 are the reverse cumulative distribution (RCD) curves of neutralizing 174 antibody titers. Higher neutralizing antibody titers were observed in the MVC group. At the referred 175 point of $60 \%$ for the AZ group, participants had neutralizing antibody titers equal to or less than 199.5

$176 \mathrm{IU} / \mathrm{mL}$. This is equivalent to approximately $90 \%$ of individuals given MVC.

\section{Sensitivity Analysis}

The sensitivity analyses conducted to detect the robustness of GMT results reveal that both

179 AZD1222 and MVC-COV1901 enhanced neutralizing antibody titers in both the subset of the younger

180 individuals (aged 20-64 years) and the overall sample which includes older participants aged 65 years

181 and above. The GMT Ratio (AZ vs. MVC) in the younger group which was 3.89 (95\% CI: 3.45, 4.4)

182 was comparable to the overall GMT Ratio of $3.55(3.2,3.97)$. The subgroup of younger individuals

183 had higher GMTs for both AZ (185.97; 95\% CI: 167.3, 206.7) and MVC (723.6; 95\% CI: 683.7, 765.8) 
medRxiv preprint doi: https://doi.org/10.1101/2022.02.26.22271364; this version posted March 1, 2022. The copyright holder for this preprint (which was not certified by peer review) is the author/funder, who has granted medRxiv a license to display the preprint in perpetuity.

It is made available under a CC-BY 4.0 International license .

184 as compared to the overall GMTs for AZ (184.05; 95\%CI: 166.5, 204.7) and MVC (654.07; 95\% CI:

185 620.9, 689.03). Adjusting for age, sex, Body Mass Index (BMI) and comorbidity status, the population

186 including 65 years and above has a more robust MVC response albeit comparable to those in the

187 younger age group. The GMT ratio (MVC vs. AZ) in the overall sample is 3.80 (95\% CI: 3.4, 4.3)

188 while that of the younger subset is 3.78 (95\% CI: 3.3, 4.3). Adjusted GMTs also indicate a better

189 response among the younger age group (Table 2). Findings are consistent when looking at the worst

190 modified subset of the sample (i.e. Day 57 titer $\leq 67$ th percentile). GMTs are lower in the overall

191 sample which includes those 65 years and above, than in the younger group (Table 3). Adjusted GMT

192 ratio is also comparable between the overall sample $(2.70 ; 95 \%$ CI: $2.4,3.01)$ and the younger age

193 group (2.69; 95\% CI: 2.4, 3.02). Subgroup analyses based on gender and comorbidity profile show

194 consistency in estimates across subgroups.

195

196 Discussion

197 The major regulators considered that the evidence from studies with authorized COVID-19

198 vaccines is sufficient to support using neutralizing antibody titers as primary endpoint in an

199 immunogenicity bridging study for authoring new COVID-19 vaccines. The decision had become

200 relevant when clinical endpoint efficacy studies are less feasible. Our study followed the statement

201 made by The International Coalition of Medicines Regulatory Authorities (ICMRA) [10]

202 demonstrating the superiority of immunogenicity of MVC-COV1901 against AZ to predict vaccine

203 effectiveness.

204 The regulator's consortium recommended that the study design should be non-inferiority when

205 the choice of the active comparator has demonstrated high efficacy, or superiority if the active 206 comparator has modest efficacy. AZ being a product that has modest efficacy justified the need for 207 demonstrating the superiority to gain regulatory approval. Our study tried to simulate the 208 immunogenicity comparison between MVC-COV1901 and AZ done by the regulator in Taiwan 209 through which a EUA was granted to the former vaccine. The comparative study was not done in a 
medRxiv preprint doi: https://doi.org/10.1101/2022.02.26.22271364; this version posted March 1, 2022. The copyright holder for this preprint (which was not certified by peer review) is the author/funder, who has granted medRxiv a license to display the preprint in perpetuity.

It is made available under a CC-BY 4.0 International license .

210 randomized, blinded study, but an external comparison. To increase confidence from the regulator's

211 perspective, a series of sensitivity analyses were conducted. The data showed that after omitting the

212 highest 33 percent data points of neutralizing antibody titers, the results can still hold.

213 The neutralizing antibody titers were determined using World Health Organization

214 (WHO)-certified reference standards, International Unit, IU/mL. The use of the standardized unit to

215 report humoral immunogenicity could facilitate future cross-platform or cross-lab comparison. The

216 study participants of both vaccines are mainly Taiwanese, reporting in IU/mL could follow

217 cross-ethnicity comparison.

218 There are a few limitations of this study, first, the design is not randomized, double blinded, but

219 an external comparison, which will compromise the level of evidence. Second, the cell-medicated

220 immunity was not included in the comparative immunogenicity profile. Third, other characterizations

221 that are of interests, including the waning immunity of both vaccines, the cross-reactivity against

222 Variants of Concern (VoCs), were not explored.

223 The data presented in the study showed that it is reasonably likely that the vaccine efficacy of

224 MVC-COV1901 is similar or superior to that of AZ. The data could be used in support of further

225 vaccine development and regulatory approval. 
medRxiv preprint doi: https://doi.org/10.1101/2022.02.26.22271364; this version posted March 1, 2022. The copyright holder for this preprint (which was not certified by peer review) is the author/funder, who has granted medRxiv a license to display the preprint in perpetuity.

It is made available under a CC-BY 4.0 International license .

Acknowledgements: The study was funded by Medigen Vaccine Biologics (study sponsor) and the

Taiwan Centres for Disease Control, Ministry of Health and Welfare.

228

229 Author Contributions: Conceptualization, C.-Y. C. and I.-F. L.; methodology, I.-F. L.; software, 230 C.-Y. C. and I.-F. L.; validation, S.-Y. K., C.-P. C., and Y.-C. L.; formal analysis, C.-Y. C., I.-F. L., 231 and J.A.G.E.; investigation, C.-Y. C. and S.-H. C.; resources, C.-Y. C., H.-C. H., H.-W. Y. and S.-H. 232 C.; data curation, I.-F. L. and J.A.G.E.; writing-original draft preparation, C.-Y. C. and J.A.G.E.; 233 writing-review and editing, I.-F. L.; visualization, J.A.G.E and I.-F. L.; supervision, I.-F. L.; project 234 administration, C.-Y. C. All authors have read and agreed to the published version of the manuscript.

Competing Interests: J.A.G.E. is an employee of Medigen Vaccine Biologics (Taipei, Taiwan) and

237 he has received grants from Taiwan Centres for Disease Control, Ministry of Health and Welfare, 238 during the conduct of the study. All other authors declare no conflict of interest.

\section{References}

241 1. Kuo TY, Lin MY, Coffman RL, et al. Development of CpG-adjuvanted stable prefusion

SARS-CoV-2 spike antigen as a subunit vaccine against COVID-19. Sci Rep, 2020; 10:20085.

243 2. Taiwan Centers for Disease Control. Taiwan National Infectious Disease Statistics System. 2021. Available at: https://nidss.cdc.gov.tw/en/nndss/Cdcwnh07?id=19CoV. Accessed October 7, criteria for locally developed COVID-19 vaccine (In Traditional Chinese). June 10, 2021. 
medRxiv preprint doi: https://doi.org/10.1101/2022.02.26.22271364; this version posted March 1, 2022. The copyright holder for this preprint (which was not certified by peer review) is the author/funder, who has granted medRxiv a license to display the preprint in perpetuity.

It is made available under a CC-BY 4.0 International license .

249 4. Hsieh SM, Liu MC, Chen YH, Lee WS, Hwang SJ, Cheng SH, Ko WC, Hwang KP, Wang NC,

250 Lee YL, Lin YL. Safety and immunogenicity of CpG 1018 and aluminium hydroxide-adjuvanted

251 SARS-CoV-2 S-2P protein vaccine MVC-COV1901: interim results of a large-scale,

252 double-blind, randomised, placebo-controlled phase 2 trial in Taiwan. The Lancet Respiratory

$253 \quad$ Medicine. 2021 Oct 13.

254 5. Blanchard B and Lee Y. “Taiwan approves Medigen's COVID-19 vaccine candidate”. July 19,

255 2021. Available at:

https://www.reuters.com/world/asia-pacific/taiwan-approves-production-medigens-covid-19-va

257 ccine-candidate-2021-07-19/"'. Accessed September 17, 2021.

258 6. International Coalition of Medicines Regulatory Authorities. ICMRA COVID-19 Vaccine

259 development: Future steps Workshop. June 24, 2021. Available at:

260 http://www.icmra.info/drupal/en/covid-19/24june2021. Accessed October 7, 2021.

261 7. Hannah B. European Pharmaceutical Review. "Immuno-bridging studies are sufficient for

262 authorising new COVID-19 vaccines, say regulators”. September 16, 2021. Available at:

https://www.europeanpharmaceuticalreview.com/news/162653/immuno-bridging-studies-are-su

264 fficient-for-authorising-new-covid-19-vaccines-say-regulators/. Accessed October 7, 2021.

265 8. Medicines and Healthcare products Regulatory Agency, UK. Access Consortium: Alignment

266 with ICMRA consensus on immunobridging for authorising new COVID-19 vaccines.

267 September 15, 2021. Available at: 
medRxiv preprint doi: https://doi.org/10.1101/2022.02.26.22271364; this version posted March 1, 2022. The copyright holder for this preprint (which was not certified by peer review) is the author/funder, who has granted medRxiv a license to display the preprint in perpetuity.

It is made available under a CC-BY 4.0 International license .

$271 \quad$ October 7, 2021.

272 9. MVC-COV1901 COVID-19 vaccine package insert. Medigen Vaccine Biologics Corp., Taipei, Taiwan. 2021.

274 10. Therapeutic Goods Administration, Australia. Access Consortium: Alignment with ICMRA

275 consensus on immunobridging for authorising new COVID-19 vaccines. September 14, 2021.

$276 \quad$ Available at:

277 https://www.tga.gov.au/access-consortium-alignment-icmra-consensus-immunobridging-authori 
medRxiv preprint doi: https://doi.org/10.1101/2022.02.26.22271364; this version posted March 1, 2022. The copyright holder for this preprint (which was not certified by peer review) is the author/funder, who has granted medRxiv a license to display the preprint in perpetuity.

It is made available under a CC-BY 4.0 International license .

\section{Tables}

289 Table 1. Demographics of the population groups

\begin{tabular}{|c|c|c|c|c|}
\hline \multirow{3}{*}{ Item\MVC lot } & \multicolumn{2}{|c|}{$<65$ years } & \multicolumn{2}{|c|}{ All ages } \\
\hline & $\begin{array}{l}\text { AstraZeneca } \\
\text { ChAdOx1 } \\
\text { nCoV-19 }\end{array}$ & MVC-COV1901 & $\begin{array}{l}\text { AstraZeneca } \\
\text { ChAdOx1 } \\
\text { nCoV-19 }\end{array}$ & $\begin{array}{l}\text { MVC- } \\
\text { COV1901 }\end{array}$ \\
\hline & $N=194$ & $\begin{array}{l}\text { PPI subset } \\
\mathrm{N}=682\end{array}$ & $N=200$ & $\begin{array}{l}\text { PPI subset } \\
\mathrm{N}=903\end{array}$ \\
\hline \multicolumn{5}{|l|}{-Age (years) } \\
\hline Mean (SD) & $42.2(11.1)$ & $38.02(11.03)$ & $42.9(11.7)$ & $45.68(16.64)$ \\
\hline Median (IQR) & $41(16.75)$ & $37.0(17.0)$ & $41.5(17.2)$ & $42.0(32.0)$ \\
\hline $\operatorname{Min} \sim \operatorname{Max}$ & $22.0 \sim 64.0$ & $20.0 \sim 64.0$ & $22.0 \sim 69.0$ & $20.0 \sim 87.0$ \\
\hline \multicolumn{5}{|l|}{$\square$ Gender } \\
\hline Male & $78(40.2)$ & $386(56.6)$ & $80(40.0)$ & $521(57.7)$ \\
\hline Female & $116(59.8)$ & $296(43.4)$ & $120(60.0)$ & $382(42.3)$ \\
\hline \multicolumn{5}{|l|}{$\square B M I\left(\mathbf{k g} / \mathbf{m}^{2}\right)$} \\
\hline Mean (SD) & $25.3(4.5)$ & $24.9(4.3)$ & $25.2(4.6)$ & $24.9(4.1)$ \\
\hline Median (IQR) & $254.6(5.97)$ & $24.3(5.7)$ & $24.5(5.97)$ & $24.4(5.3)$ \\
\hline Min Max & $16.6 \sim 39.6$ & $14.3 \sim 45.2$ & $17.01 \sim 37.5$ & $17.7 \sim 36.9$ \\
\hline \multicolumn{5}{|l|}{$\square$ BMI group } \\
\hline$<30 \mathrm{~kg} / \mathrm{m}^{2}$ & $159(81.96)$ & $594(87.1)$ & $798(88.4)$ & $164(82.0)$ \\
\hline$>=30 \mathrm{~kg} / \mathrm{m}^{2}$ & $35(18.04)$ & 88 (12.9) & 105 (11.6) & $36(18.0)$ \\
\hline \multicolumn{5}{|c|}{$\square$ Pre-vaccination neutralizing antibody status } \\
\hline Seropositive & $2(1.03)$ & $8(1.17)$ & $2(1.0)$ & $10(1.11)$ \\
\hline Seronegative & $192(98.97)$ & $674(98.83)$ & $198(99.0)$ & $893(98.9)$ \\
\hline \multicolumn{5}{|l|}{$\square$ Comorbidity Category } \\
\hline at least one comorbidity & $74(38.1)$ & $89(13.0)$ & $123(61.5)$ & $729(80.7)$ \\
\hline No comorbidity & $120(61.9)$ & $593(87.0)$ & $77(38.5)$ & $174(19.3)$ \\
\hline
\end{tabular}


medRxiv preprint doi: https://doi.org/10.1101/2022.02.26.22271364; this version posted March 1, 2022. The copyright holder for this preprint (which was not certified by peer review) is the author/funder, who has granted medRxiv a license to display the preprint in perpetuity.

It is made available under a CC-BY 4.0 International license .

291 Table 2. Neutralizing antibody titer in subjects immunized with either two doses of AZD1222 or

292 MVC-COV1901 in all ages and ages 20-64 years at Day 57 (28 days after the second dose)

\begin{tabular}{|c|c|c|c|c|c|c|}
\hline \multirow{5}{*}{$\begin{array}{c}\text { ItemIMVC } \\
\text { lot }\end{array}$} & \multicolumn{3}{|c|}{$<65$ years* } & \multicolumn{2}{|c|}{ All ages } & \multirow{5}{*}{ p-value } \\
\hline & AstraZeneca & & \multirow{4}{*}{ p-value } & AstraZeneca & & \\
\hline & $\begin{array}{l}\text { ChAdOx1 } \\
\text { nCoV-19 }\end{array}$ & MVC-COV1901 & & $\begin{array}{l}\text { ChAdOx1 } \\
\text { nCoV-19 }\end{array}$ & MVC-COV1901 & \\
\hline & & PPI subset & & & PPI subset & \\
\hline & $N=192$ & $N=674$ & & $N=198$ & $\mathbf{N}=893$ & \\
\hline GMT & 185.97 & 723.6 & & 184.05 & 654.07 & \\
\hline $\begin{array}{l}95 \% \mathrm{CI} \\
\text { of GMT }\end{array}$ & 167.3 206.7 & $683.7 \sim 765.8$ & & $166.5 \sim 204.7$ & $620.9 \sim 689.03$ & \\
\hline
\end{tabular}

GMT

$\begin{array}{lll}\text { Ratio } & 3.89 & 3.55\end{array}$

(MVC/AZ)

$95 \% \mathrm{CI}$

$<0.0001$

$<0.0001$

of GMT

$3.45 \sim 4.4$

3.2 3.97

Ratio

Adjusted

GMT

Ratio

(MVC/AZ)

$95 \%$ CI

of Adjusted

$3.3 \sim 4.3$

$3.4 \sim 4.3$

GMT Ratio

*The GMT Ratio was adjusted for age, gender, BMI, and comorbidity profile using general linear models.

295 Table 3. Worst modified PPI subset of neutralizing antibody titer in subjects immunized with either two

296 doses of AZD1222 or MVC-COV1901 in all ages and ages 20-64 years at Day 57

\begin{tabular}{lll}
\hline$<65$ years* $^{*}$ & All ages \\
\cline { 2 - 3 }
\end{tabular}


medRxiv preprint doi: https://doi.org/10.1101/2022.02.26.22271364; this version posted March 1, 2022. The copyright holder for this preprint (which was not certified by peer review) is the author/funder, who has granted medRxiv a license to display the preprint in perpetuity.

It is made available under a CC-BY 4.0 International license.

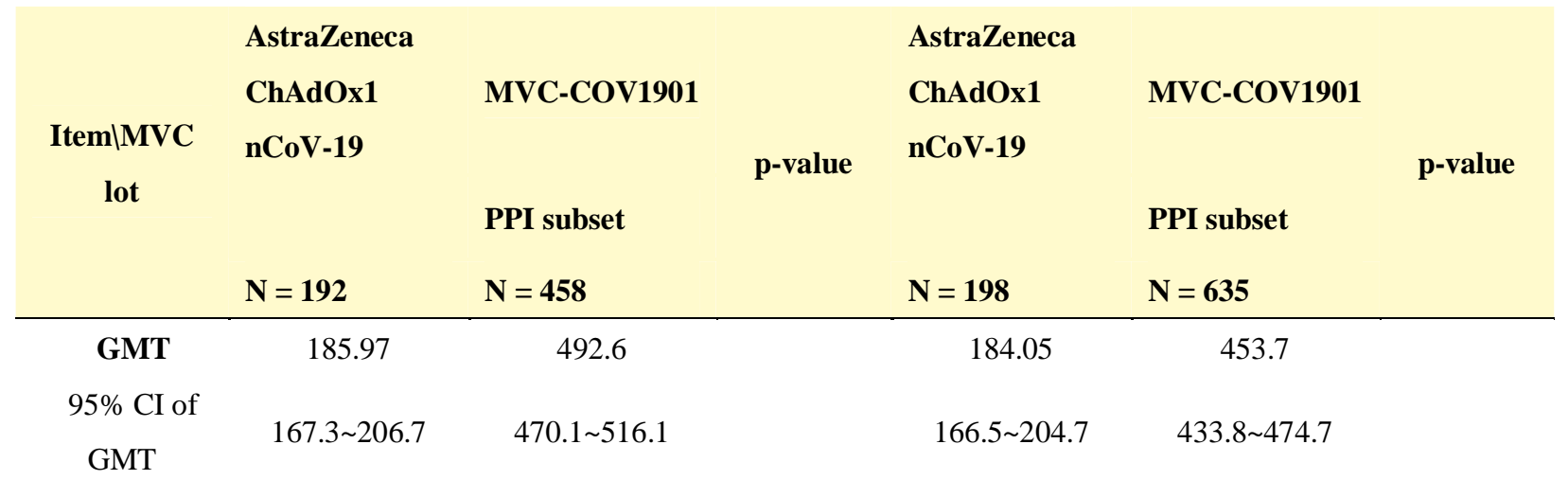

$\begin{array}{cccc}\text { GMT Ratio } & 2.65 & & 2.46 \\ \text { (MVC/AZ) } & & <0.0001 & \\ \text { 95\% CI of } & 2.4 \sim 2.97 & 2.2 \sim 2.7 \\ \text { GMT Ratio } & & & \end{array}$

Adjusted

GMT Ratio

2.6

2.62

(MVC/AZ)

$<0.0001$

$<0.0001$

$95 \%$ CI of

Adjusted

$2.3 \sim 2.9$

$2.3 \sim 2.9$

GMT Ratio

* The GMT Ratio was adjusted for age, gender, BMI, and comorbidity profile using general linear models. 
medRxiv preprint doi: https://doi.org/10.1101/2022.02.26.22271364; this version posted March 1, 2022. The copyright holder for this preprint (which was not certified by peer review) is the author/funder, who has granted medRxiv a license to display the preprint in perpetuity.

It is made available under a CC-BY 4.0 International license.

\section{Figures}

298
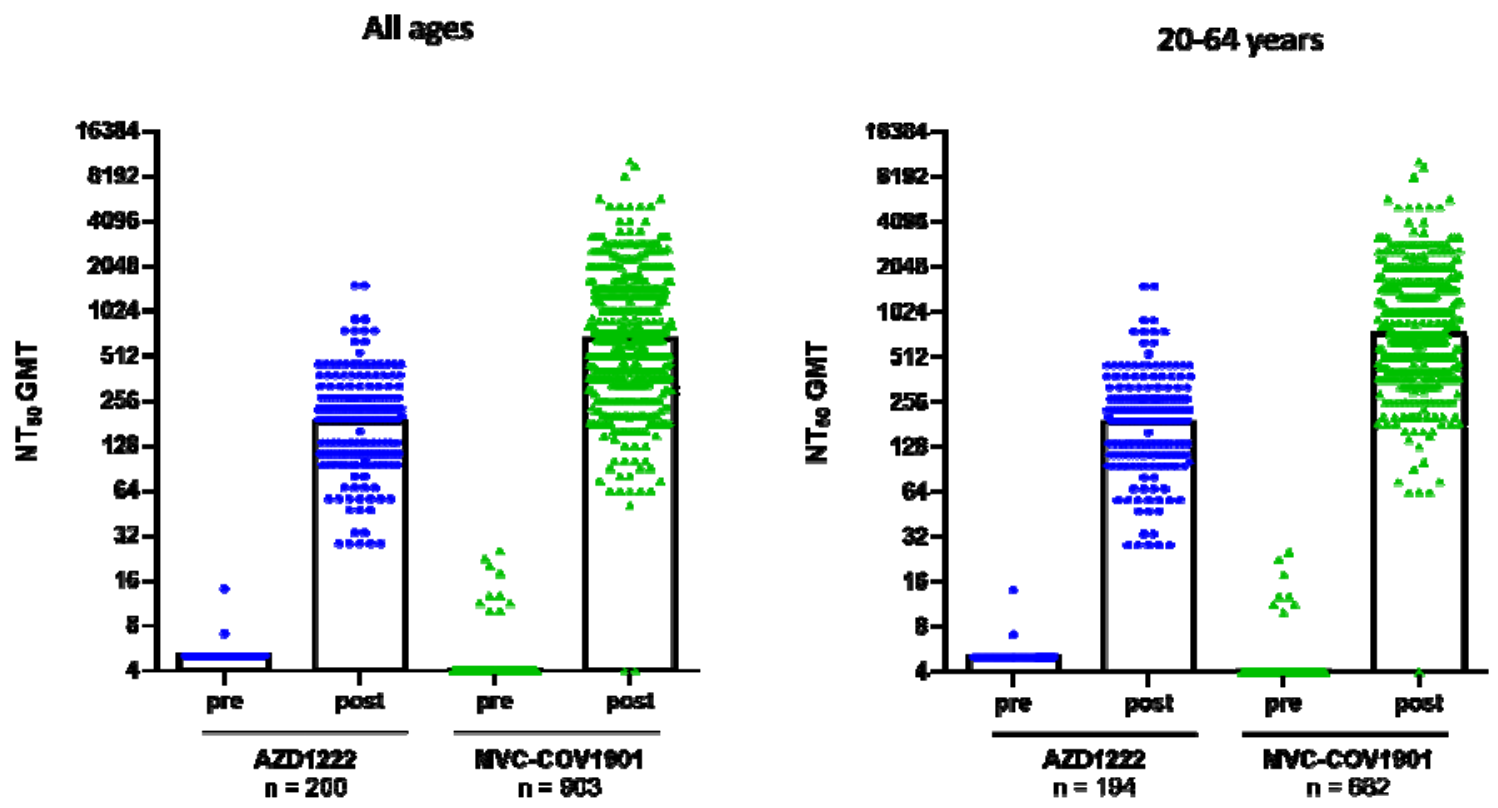

Figure 1. Neutralizing antibody titer in subjects immunized with two doses of either AZD1222 or MVC-COV1901 in all ages (left) and ages 20-64 years (right)

Serum samples were taken before the first vaccination (pre) or 28 days (post) after the second dose of either

303 vaccine and were subjected to live SARS-CoV-2 neutralization assay. The results are shown as 50\%

304 neutralizing titer $\left(\mathrm{NT}_{50}\right)$ with symbols indicating individual $\mathrm{NT}_{50}$ values and the bars indicating the GMT of

305 each group.

306 
medRxiv preprint doi: https://doi.org/10.1101/2022.02.26.22271364; this version posted March 1, 2022. The copyright holder for this preprint (which was not certified by peer review) is the author/funder, who has granted medRxiv a license to display the preprint in perpetuity.

It is made available under a CC-BY 4.0 International license .

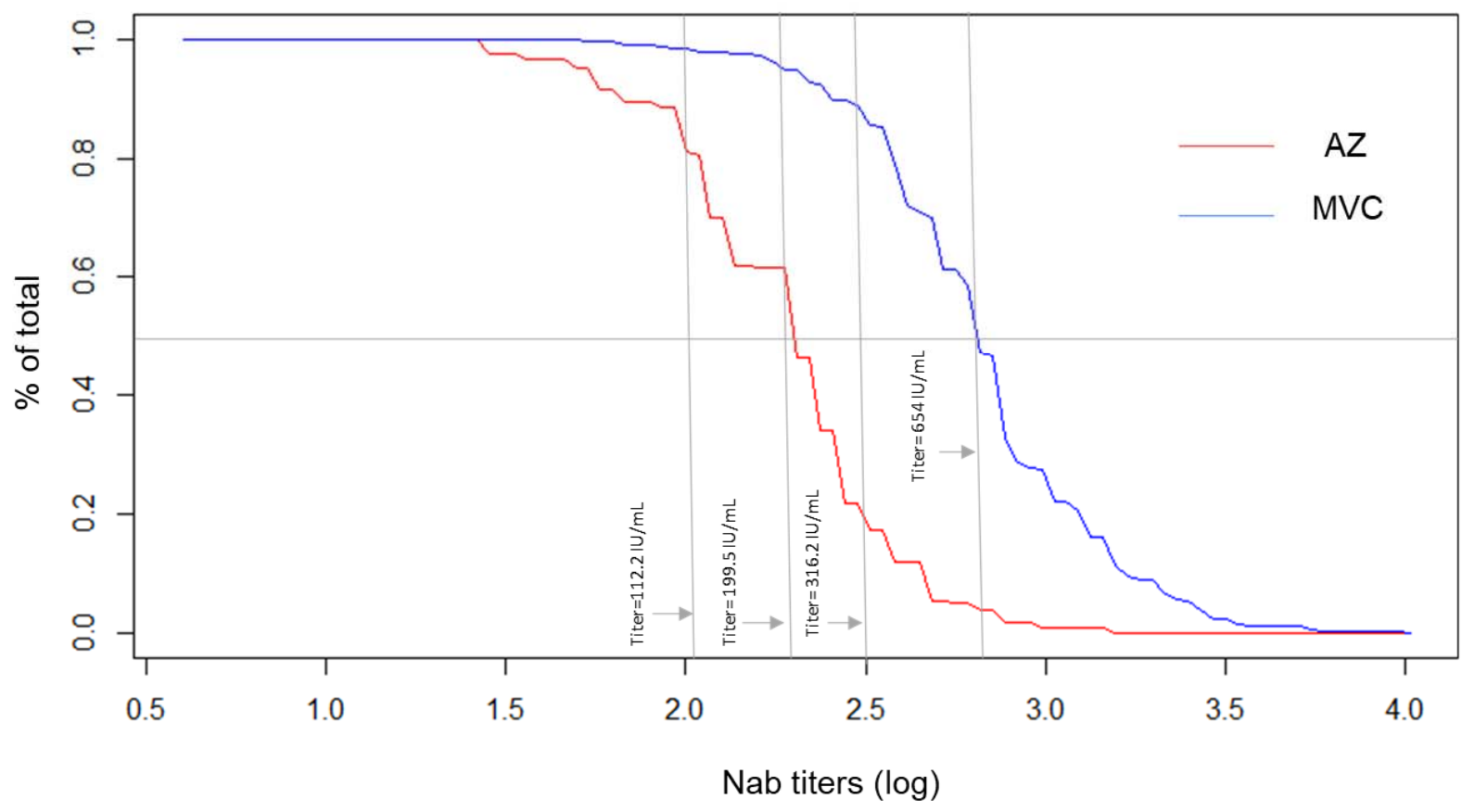

309

Figure 2. Reverse Cumulative Distribution Curve using log-transformed titers by percent of subjects who

310 had neutralizing antibody titers 28 days following the second dose of AZ and MVC 


\section{All ages}

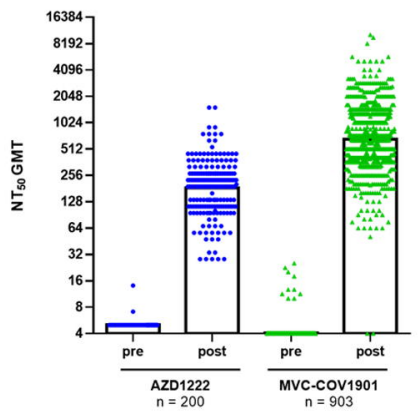

\section{0-64 years}

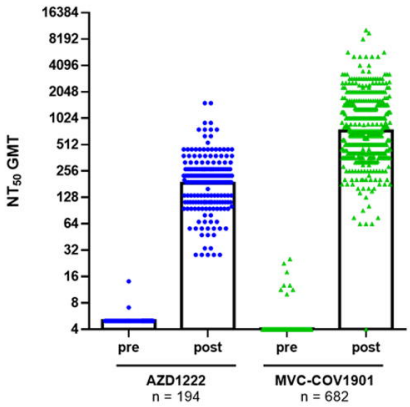


